\title{
Innovation of Sustainable and Greener Raised Median or Road Divider on Expressway
}

\author{
Kamarudin Ambak ${ }^{1 *}$, Norfatehah Abdul Rahim ${ }^{1}$, Naida Rosli ${ }^{1}$ \\ ${ }^{1}$ Smart Driving Research Centre, Faculty of Civil and Environmental Engineering, \\ Universiti Tun Hussein Onn Malaysia, 86400 Parit Raja, Batu Pahat, Johor, MALAYSIA.
}

*Corresponding Author

DOI: https://doi.org/10.30880/ijscet.2020.11.03.004

Received 26 May 2019; Accepted 21 March 2020; Available online 30 June 2020

\begin{abstract}
This study purposes a new innovation design for the construction of road divider that more sustainable and greener which is eco-friendly. It was conducted to modify the material used on the road divider, so that the suitability of the material can reduce the impact of the vehicle during road accident. Objective of this study is to test and design greener sustainable materials as a road median component. Besides, the study is to determine the suitability and characteristics of materials for road median. Materials used in this study are gunny sacks filled with sand, laterite soil, soft turfing (cow and pearl grass) and used tire as a cushion effect. Based on experiment testing, sieve analysis result showed that river sand is a good grade sand and suitable for road median. While, direct shear test showed sand and soil used for this study are suitable because there have a high shear strength. For grass observation, cow grass is suitable compare pearl grass in term of growth rate, maintenance cost, durability on sunlight exposure and weather in Malaysia. The load applied for conducting impact test on the sand sack were 14.08N 25.6N $44.8 \mathrm{~N}$. The initial damage occurred when a force reaches at $44.8 \mathrm{~N}$. However, the condition of the arrangement of sand sack is still stable. In conclusion, this new innovation of green and sustainable road divider has high potential in absorbing the impact of accidents.
\end{abstract}

Keywords: Median, sustainable, innovation, impact

\section{Introduction}

The development of road construction in Malaysia was showed a good growth with the use of hi-tech equipment. However, it's failed to prevent road accident impact when involving the road facilities especially road barrier. Road Safety Department [1] was indicated that $80.6 \%$ of road accident is due to human negligence, $13.2 \%$ due to environment or condition of road and only $6.2 \%$ due to vehicle condition. Even though environment of road was recorded only $13.2 \%$, however road facilities is one of the factors needs to be focusing on because impacts on injuries during a road accident causing the function of road facilities were doubting. This is because, road barrier function of protecting the driver is in an unsatisfactory level [2]. In general, road barrier function is to reduce the acceleration of the vehicle is either slowly rubbing or sudden stopped, which will result in greater impact [2]. Nevertheless, the used of concrete and rail on road barrier doesn't help to reduce any accident impact [3], even it cause the vehicle more worse during accident occur and also have a negative effect towards environment [3]. Therefore, the study of innovation on green and sustainable raised road median at multi-lane highway is conducted to determine the effectiveness in replacing the existing road divider.

The use of cement and guardrails will replaced with new materials which are sand sacks, laterite soil, soft turfing (cow and pearl grass) and used tires as a cushion effect. The objectives to innovate the materials used for road barrier construction are to reduce the impact of accidents injury, less maintenance cost, environmental friendly and sustainable. In term of accident impact, new materials used to replace concrete and rail because concrete has a rigid surface and zero 
kinetic energy during accident impact compared than soil which has a soft surface and can absorb the kinetic energy [4]. While, for environmental concern, concrete and steel on a road barrier have a negative impact on the environment because in the process of cement preparation at factory will release cement gaseous and dust that can contribute to pollution [3]. Besides, it does not have any aesthetics values [3] and that is why it will replaced with new materials for green landscape on the road to reduce stress among road users [2]. Sand sack as a median barrier also used in earth house which is one of the green technology in housing construction [5]. This material was used as flood barrier (Pelly, 2009) and inspired for this study to apply for road median because of its strength.

\section{Materials and Methods}

In this study, the existence of road divider was studied in terms of material and structure. This information is obtained from the Public Work Department Guidelines Arahan Teknik (Jalan) 1/8 6 [6]. Therefore, the green and sustainable raised road median is proposed and to be designed.

\subsection{Conceptual Design of Green Median}

Height of guardrails that commonly applied in Malaysia is about $600 \mathrm{~mm}$ to $800 \mathrm{~mm}$ according to Arahan Teknik (Jalan) 1/86 [6]. This range of height is applied in the design of green and sustainable raised road median. The height used is according to the type of road median constructed which is based on the speed limit of a highway [7]. In designing green median, the height of the median is follow the requirement of the specification Public Works Department (JKR). The width of road median allowed according to the Arahan Teknik Jalan 8/86 [6] is 1000mm to 3000mm. Figure 1 shows the design concept of the green and sustainable raised road median using Sketchup software.

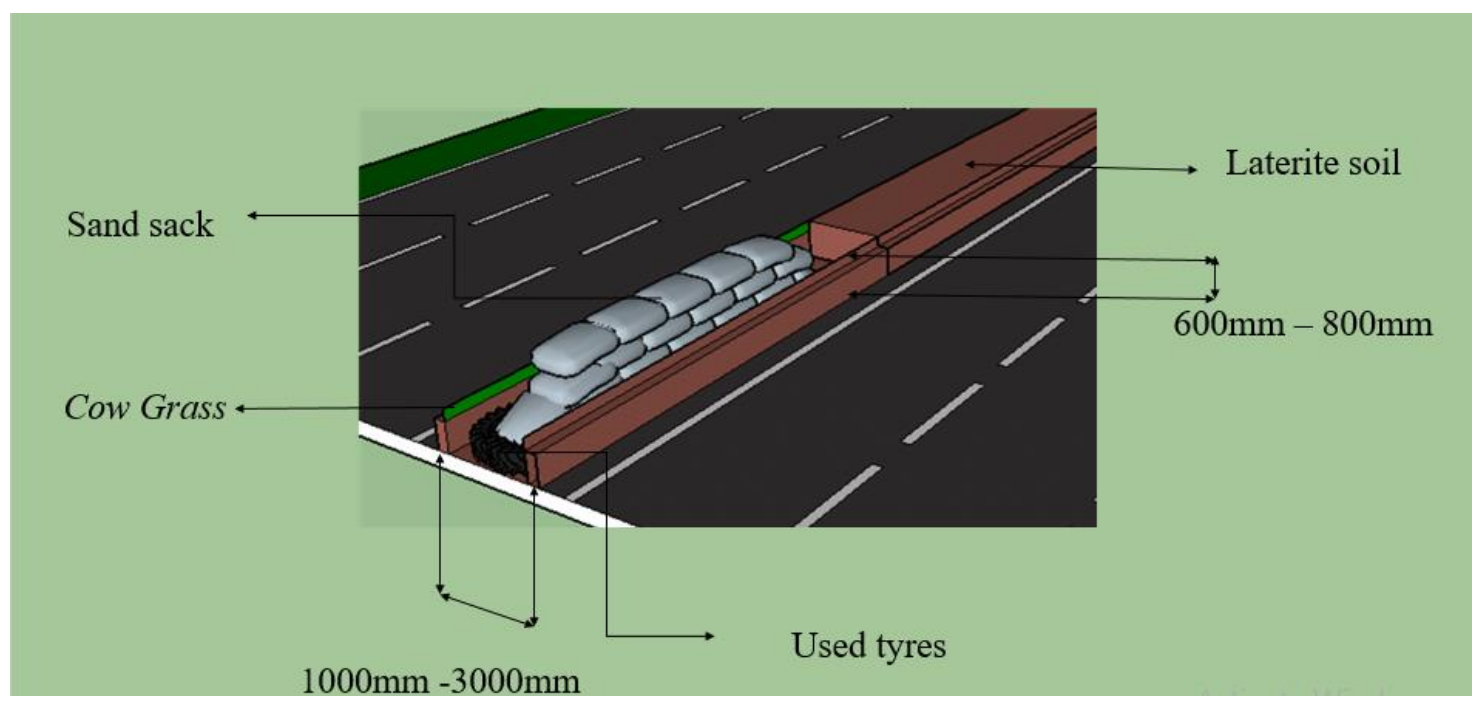

Fig. 1 - The design concept of the green and sustainable raised road median

\subsection{Selection of Materials}

This study uses green and sustainable materials to reduce steel and cement used in road facilities construction. Table 1 shows the list of materials used for green and sustainable raised road median.

Table 1 - List of materials used for green and sustainable raised road median

\begin{tabular}{ccll}
\hline No & Material & \multicolumn{1}{c}{ Description } & \multicolumn{1}{c}{ Testing } \\
\hline 1 & Sand & -Fine aggregates & 1) Sieve Analysis Test \\
& -Most suitable because it cleans from other \\
& chemical impurities & $\begin{array}{l}\text {-conducted according to the British } \\
\text { Standard (BS812: Part 103.1:1985) } \\
\text { - The texture of sand river is rougher and have a } \\
\text { high durability to restrain crash impact that cause } \\
\text { from road accident. }\end{array}$ & $\begin{array}{l}\text { 2) Direct Shear Test } \\
\text { conducted according to the British } \\
\end{array}$ \\
& & $\begin{array}{l}\text { Standard (B377:1990) } \\
\text {-to determine the shear strength of the sand } \\
\text { sample }\end{array}$ \\
\hline
\end{tabular}




\begin{tabular}{|c|c|c|c|}
\hline & & & $\begin{array}{l}\text {-strength need to measure because sand } \\
\text { will receive crash impact during road } \\
\text { accident. }\end{array}$ \\
\hline 2 & Laterite Soil & $\begin{array}{l}\text {-function as a covered soil to protect the internal } \\
\text { component of road median } \\
\text {-aid to form road median } \\
\text {-as a soft cover material for grass breeding and } \\
\text { covering the entire road median to look greener and } \\
\text { have an aesthetic value. }\end{array}$ & $\begin{array}{l}\text { 1) Direct Shear Test } \\
\text { conducted according to the British } \\
\text { Standard (B377:1990) } \\
\text {-to determine the shear strength of the sand } \\
\text { sample } \\
\text {-shear strength of soil, cohesion (c), angle } \\
\text { of friction }(\varnothing) \text { and the strength of soil will } \\
\text { identified through this testing. }\end{array}$ \\
\hline 3 & Used Tires & $\begin{array}{l}\text {-Function as a cushion effect } \\
\text {-as a soft barrier for early protection towards sand } \\
\text { sack } \\
\text {-Tire used in medium sized and not too large } \\
\text {-Small tire size are unsuitable as a cushion effect to } \\
\text { restrain initial crash impact }\end{array}$ & \\
\hline 4 & Grass & $\begin{array}{l}\text {-Used as a vegetative in the construction of green } \\
\text { and sustainable raised road median. } \\
\text {-Cow Grass (Axonopous Compressus) and pearl } \\
\text { grass are selected to construct green and } \\
\text { sustainable road median. } \\
\text {-The grip of grass root helps to strengthen the } \\
\text { structure of the median path. }\end{array}$ & $\begin{array}{l}\text { 1) Observation on the grass growth } \\
\text {-the grass will planting on the laterite soil } \\
\text { - The grass container will be placed outside } \\
\text { building. } \\
\text {-the length of the roots will observed and } \\
\text { measured within } 60 \text { days. } \\
\text { - The growth of these two grass will be } \\
\text { compared and the best grass's growth will } \\
\text { be selected as a vegetative material in } \\
\text { sustainable road median construction. }\end{array}$ \\
\hline \multirow[t]{2}{*}{5} & Gunny sack & $\begin{array}{l}\text {-filled with sand } \\
\text {-main material for road median construction } \\
\text {-The types of sand sack proposed is polypropylene } \\
\text { type. } \\
\text {-polypropylene was proposed because it has a high } \\
\text { durability, strong, non-biodegradeable and }\end{array}$ & $\begin{array}{l}\text { 1) Crash Test } \\
\text {-to determine the strength of sand sack } \\
\text { (main material as an accident impact } \\
\text { absorber) } \\
\text {-this test will similar as an impact test that } \\
\text { was conducted by Virginia Technology. }\end{array}$ \\
\hline & & & $\begin{array}{l}\text { Fig. } 2 \text { - Impact Test by Virginia } \\
\text { Technology [8] }\end{array}$ \\
\hline 6 & Pipe & $\begin{array}{l}\text {-Types of pipes that used for road median is } \\
\text { polyvinyl chloride (PVC) } \\
\text {-PVC pipe has a high durability and long life span } \\
\text {-This pipe will be cultivated between sand sacks } \\
\text { where it will located in the middle of the road } \\
\text { median. }\end{array}$ & \\
\hline
\end{tabular}

\subsection{Simulation of Sustainable Road Median}


The road median simulation is required for this study to compare manual impact test result and the constraints caused lack of equipment to test the impact on the road median. The simulation software used for this study are Solid Work and ANYSS. ANYSS is a general purpose software used to simulate the interaction of all physics disciplines, structures, vibration, fluid dynamics, heat transfer and electromagnetic for engineer. These software is used to observe the kinetic and impact energy on the road median. Besides, the impact test from previous study with similar software also will be compared. Simulation results will support manual impact test result after comparison is made.

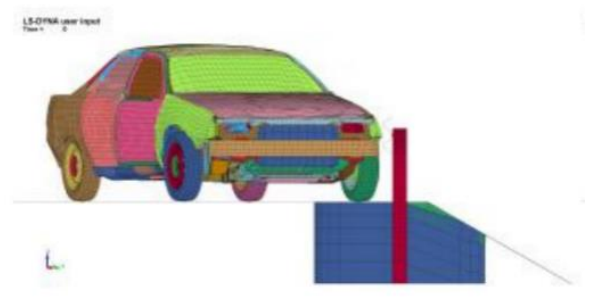

Fig. 3 - Illustration of simulation test

\section{Result and Analysis}

The results of experimental analysis have been derived from the sieve analysis and direct shear test. Each experiment was carried out to determine the properties of river sand and laterite soil that will be used as materials in sustainable road divider construction. In addition, the results of crash tests also was conducted on the arrangement of sand sack to determine the strength of sand sack. Subsequently, the Cow and Pearl grass were observe to determine the rate of grass growth.

\subsection{Sieve Analysis Test}

Sieve analysis was conducted on fine aggregates in order to check the level of sand gradation, quality and durability of sand. Fine aggregates that used for this study was sand river. Based on graph, grade of fine aggregates showed in a good grade and categorized as coarse silt. Besides, the fine modulus of sand showed 3.0 which means it can categorized as a fine aggregates. Sand can be categorized as a fine aggregates if the Fine Modulus is less than 4. Therefore, this sand is suitable to use as a road median material that will receive crash impact energy during road accident. This is because, the sand texture is not too smooth and if the crash impact applied on it, it will becoming more crush and finally turn to dust.

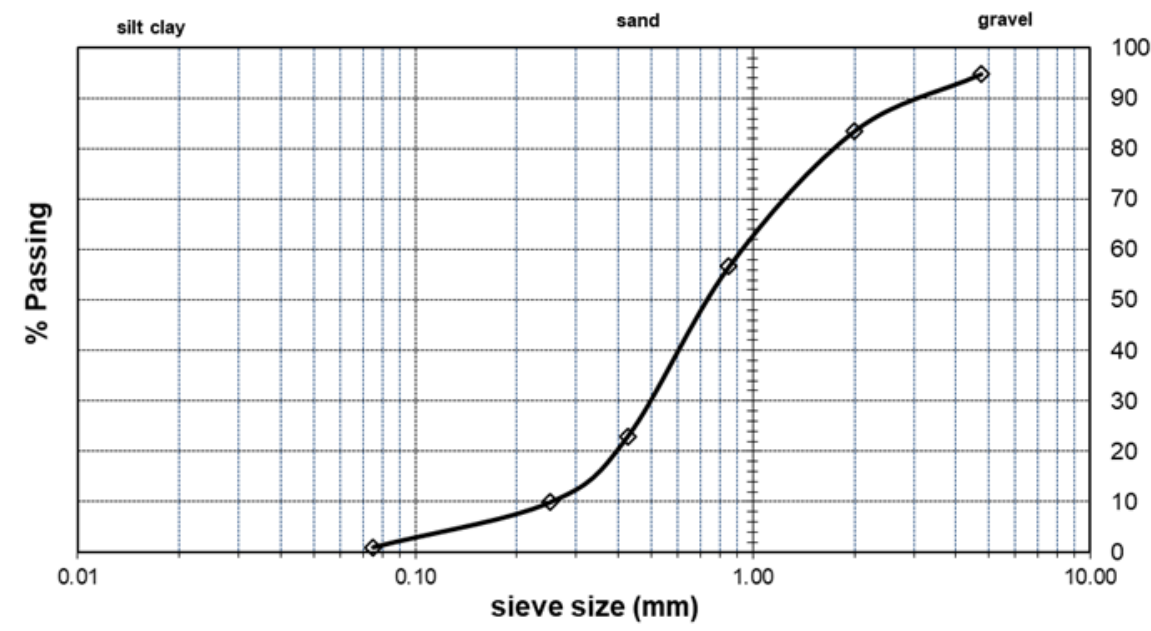

Fig. 4 - Percentage of finer against sieve size.

\subsection{Direct Shear Test}

Direct Shear test was conducted to determine the shear strength of soil and sand as part of materials in road median construction. Even though, soil is not as a main material however during road accident soil also absorb the crash impact

\subsubsection{Direct Shear Test on Laterite Soil}


Based on graph (figure), for $5 \mathrm{~kg}$ sample, shear stress achieved maximum level at $5.1 \mathrm{kN} / \mathrm{m}^{2}$ with maximum of strain at $93.3 \times 10$. While, for $10 \mathrm{~kg}$ load, shear stress achieved maximum level at $62.2 \mathrm{kN} / \mathrm{m}^{2}$ with maximum of strain at $100 \times 10$ and for $15 \mathrm{~kg}$ load, shear stress achieved maximum level at $79.4 \mathrm{kN} / \mathrm{m}^{2}$ with maximum of strain at $93.3 \times 10$. When reach shear failure, three consecutive reading showed no any change.

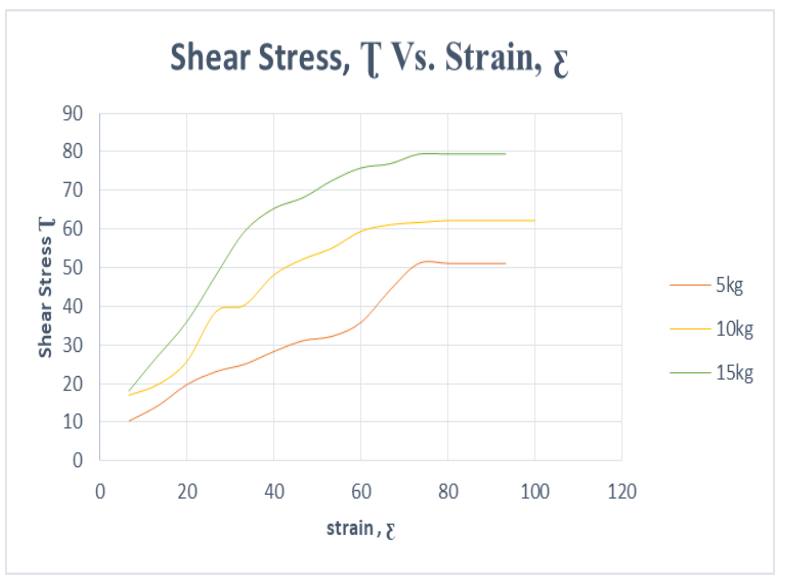

Fig. 5 - Graph of strain versus shear stress of laterite soil

Based on graph (figure), when normal stress increases, shear stress also increases. Friction angle is a linear angle produced. The value of $\mathrm{C}$ for this sample is $0 \mathrm{kN} / \mathrm{m}^{2}$. Therefore, since the friction angle of soil is $29^{\circ}$, this soil considered as a well graded soil.

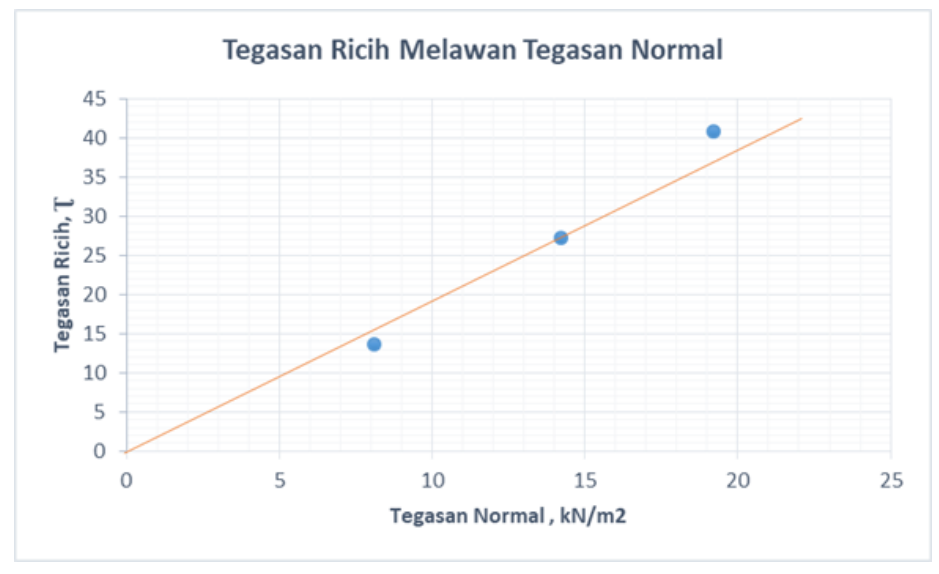

Fig. 6 - Shear stress versus normal stress of soil

\subsubsection{Direct Shear Test on Sand}

Based on graph (figure), for $5 \mathrm{~kg}$ sample, shear stress achieved maximum level at $39.7 \mathrm{kN} / \mathrm{m}^{2}$ with maximum of strain at $106.7 \times 10$. While, for $10 \mathrm{~kg}$ load, shear stress achieved maximum level at $57.8 \mathrm{kN} / \mathrm{m}^{2}$ with maximum of strain at $86.7 \times 10$ and for $15 \mathrm{~kg}$ load, shear stress achieved maximum level at $78.3 \mathrm{kN} / \mathrm{m}^{2}$ with maximum of strain at $93.3 \times 10$. When reach shear failure, three consecutive reading showed no any change. 


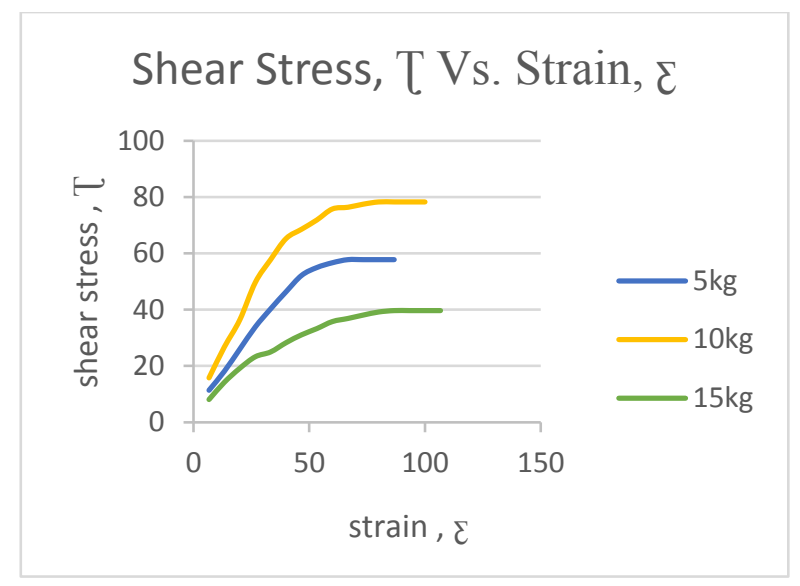

Fig. 7 - Graph of strain versus shear stress of sand

Based on graph (figure), when normal stress increases, shear stress also increases. Friction angle is a linear angle produced. The value of $\mathrm{C}$ for this sample is $5 \mathrm{kN} / \mathrm{m}^{2}$. Therefore, since the friction angle of soil is $38^{\circ}$, this soil considered as a well graded soil. Therefore, both laterite soil and river sand well graded and consider as a suitable material in this innovation.

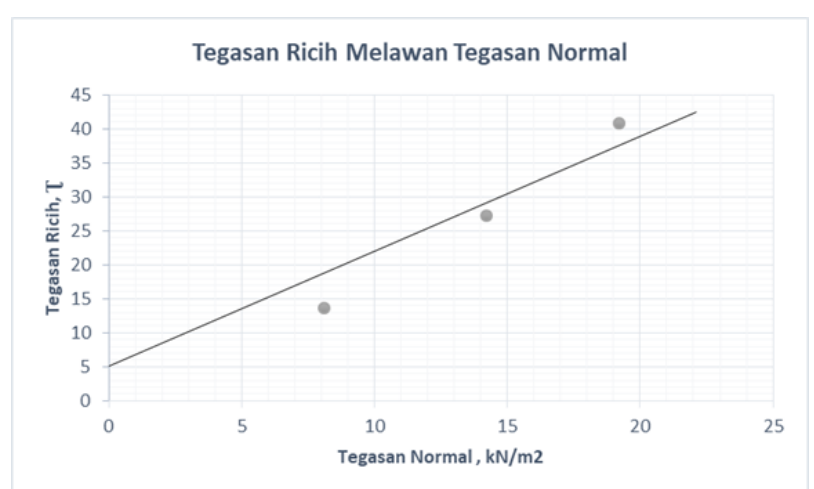

Fig. 8 - Shear stress versus normal stress of sand.

\subsection{Crash Test}

Crash test aim to determine the strength of gunny sand sack as a main material that absorb accident impact. The type of gunny sack is polypropylene with sized 22" x 36 " and have a $40 \mathrm{~kg}$ weight. Load used are $11 \mathrm{~kg}, 20 \mathrm{~kg}$ and $35 \mathrm{~kg}$. Due to the equipment constraint, maximum loads applied was $35 \mathrm{~kg}$. All loads were suspended and swung towards sand sacks that were stacked up to 4 levels as shown as figure. The distance between loads and sand sacks is $15 \mathrm{~cm}$. The first load weighing $11 \mathrm{~kg}$ represent light weight vehicle, second load was $20 \mathrm{~kg}$ represent medium weight vehicle and maximum load is $35 \mathrm{~kg}$ represent heavy vehicle. Based on Inertia Newton Law, moving object will move with fixed velocity. Based on table 1, gunny sand sack are good condition and arrangement for $11 \mathrm{~kg}(14.08 \mathrm{~N})$ and $20 \mathrm{~kg}(25.6 \mathrm{~N})$. However for load $35 \mathrm{~kg}(44.8 \mathrm{~N})$, the gunny sand sack was moved a bit. Based on Hampton [8] study, weight of a vehicle is a $1000 \mathrm{~kg}$, because of equipment constraint, the load of pendulum that can be used is $30 \mathrm{~kg}$. However, for gunny sand sacks, $40 \mathrm{~kg}$ weight is sufficient. 


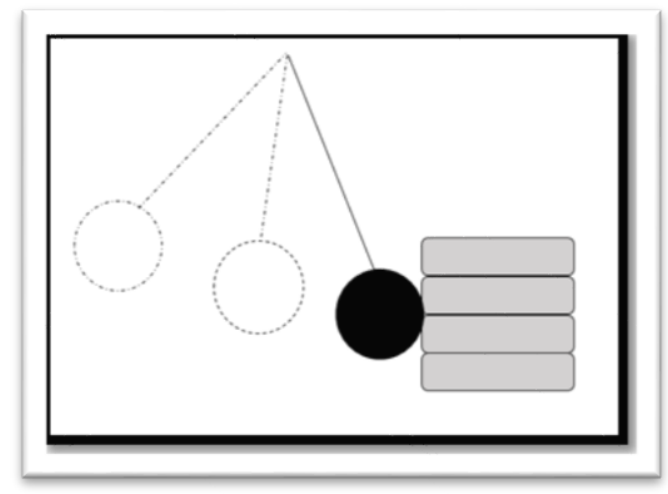

Fig. 9 - Impact test illustration

Table 1 - Acceleration and Force Applied to the Sand Sack

\begin{tabular}{cccc} 
Load $(\mathbf{k g})$ & Force $(\mathbf{N})$ & Acceleration $(\mathbf{m} / \mathbf{s})^{2}$ & Observation on sand sack \\
\hline $\mathbf{1 1}$ & 14.08 & 1.28 & Good and no deflection occur \\
$\mathbf{2 0}$ & 25.6 & 1.28 & Good and no deflection occur \\
$\mathbf{3 5}$ & 44.8 & 1.28 & Good and a little deflection occur \\
\hline
\end{tabular}

In physics, the kinetic energy of an object is the energy that it possesses due to its motion. It is defined as the work needed to accelerate a body of a given mass from rest to its stated velocity. Having gained this energy during its acceleration, the body maintains this kinetic energy unless its speed changes. In any situation where the speed changes, kinetic energy changes. The impact tests were performed using three different loads. The first load weight is represents the weight of the light vehicle while the second load weight $20 \mathrm{~kg}$. The last load is $35 \mathrm{~kg}$ representing heavy vehicles. The amount of translational kinetic energy depends upon two variables: the mass $(\mathrm{m})$ of the object and the speed (v) of the object as shown in the table below, based on the result, the more increase in velocity the more kinetic energy produced.

Table 2 - Distance and Kinetic Energy

\begin{tabular}{ccc}
\hline Velocity $(\mathbf{m} / \mathbf{s})$ & Load $(\mathbf{k g})$ & Kinetic energy $(\mathbf{k g ~ m} / \mathbf{s})$ \\
\hline 1.0 & 11 & 17.5 \\
1.2 & 20 & 25.2 \\
1.5 & 35 & 39.4 \\
\hline
\end{tabular}

\subsection{Comparison between Manual Crash Test and Simulation}

ANYSS simulation was used to compare between manual crash test impact and simulation crash test. Based on figure 10 and table 3, the difference between these two tests are still in minimum rate. Based on result obtained, the higher the number of speed, the higher and the kinetic energy. Gary et al., [9] stated that, small car with $820 \mathrm{~kg}$ weight able to give an impact towards crush cushion with speed $72 \mathrm{~km} / \mathrm{h}$. Therefore, the ratio of test towards small car is 1:8 because the system must follow the requirement of NCHRP 350 (National Cooperative Highway Research Program Report 350). Based on these two comparison between force and speed showed that the higher the number of force, the higher the number of deflection value during an impact towards road median. 


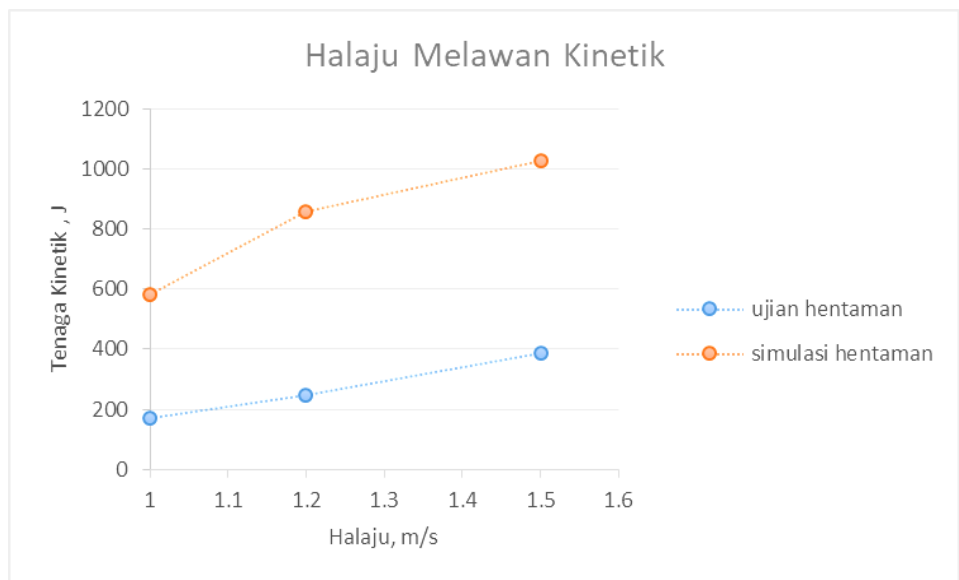

Fig. 10 Speed versus Kinetic Energy

Table 3 - The result of crash test and simulation test

\begin{tabular}{cccc}
\hline \multirow{2}{*}{ Method } & \multicolumn{3}{c}{ Speed km/h } \\
\cline { 2 - 4 } & 3.6 & 4.32 & 5.4 \\
\hline Crash Test & 171.616 & 247.127 & 386.38 \\
\hline Simulation & 580.00 & 860.00 & 1025.66 \\
\hline
\end{tabular}

The obvious difference between simulation test and crash test because distance and load towards gunny sand sack. For manual crash test, the size of gunny sand sack based on real size and arrange suitable with scale. While, simulation test as same as a load of real car. This is because, real car weight is more heave compare than the manual crash test load that using gunny sand sack. The manual crash test used small scale because of the equipment and material constraint. In a conclusion, when have an impact towards road median with distance and force, there is an increase in deflection on the road median. For manual crash test, even the deflection is $70 \mathrm{~mm}$ with the gunny sack still in a good arrangement and condition, this sustainable road median have a potential to replace road median existing to be more sustain and environmentally friendly.

\subsection{Observation on the Grass Growth (Pearl and Cow Grass)}

Based on the result, the grass was planted and grow in a container. After 14 days, the lawn is fertilized in order to speed up the grass growth. The observation on the growth of the grass was conducted and at day 60 , the grass is removed and the length of the root was measured. Based on the observation, the pearl and cow grass (figure 8), are suitable material in green median. However, there have a few criteria's to consider to choose between these two types of grass for sustainable road median. Growth rate of the pearl grass is slow compared to cow grass. Cow grass do unfertilized and do not require much water compare to pearl grass. Besides that, pearl grass cannot received direct sunlight because under direct sunlight, pear grass requires frequent watering and the edges of the grass blade starts to turn brown so pearl grass suitable at shady area compare to cow grass can grow under direct sunlight.
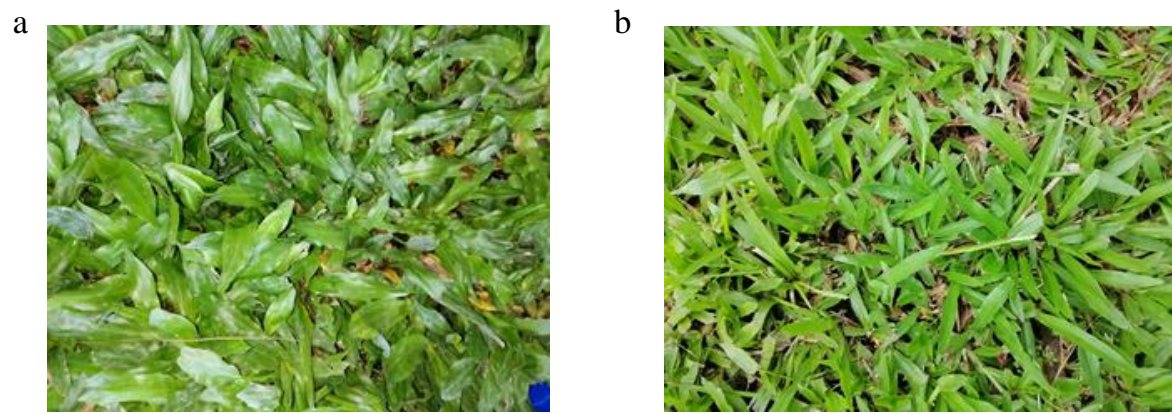

Fig. 11 - (a) Pearl Grass; (b) Cow Grass.

Cow grass is suitable to plant at slopes or roadside. Observation on the roots growth for both grass (table 3), before 60 days cow grass's root is measured $6.5 \mathrm{~cm}$ and pearl grass's roots is measured $5.4 \mathrm{~cm}$. After 60 days, it show that cow 
grass has faster rate of roots growth which is $15.5 \mathrm{~cm}$ compared to pearl grass showed slow rate of roots growth with $12.8 \mathrm{~cm}$.Roots of plant helps the grass have a stronger grip. Based on result obtained, this study conclude that, the Cow Grass as vegetative material is more durable and has a strong grip to avoid the grass from out rooted if an accident occurs at the raised road median [10]. The function of grass is also to help maintaining the shape of the raised road median.

Table 3 - The growth of roots grasses

\begin{tabular}{ccc}
\hline Type of grass & Cow grass & Mutiara \\
\hline Before 60 days & $6.5 \mathrm{~cm}$ & $5.4 \mathrm{~cm}$ \\
After 60 days & $15.5 \mathrm{~cm}$ & $12.8 \mathrm{~cm}$ \\
\hline
\end{tabular}

\section{Conclusions}

Material such as sand sack as a main material, laterite soil and used tires is a suitable material to build green and sustainable raised road median. The structure of the green and sustainable raised road median is stronger by encapsulated of laterite soil, soft turfing with cow and pearl grass and enclosed with used tires as cushion effect. In addition, Cow Grass is a suitable as a covering material to maintain the shape of the raised road median because this type of grass has a good pattern of growth. Besides that, even though real model are not create on the crash test, arrangement of sand sack itself can bear the impact, it is already cover the strength of the real model. Based on the result obtained, this study has a higher potential in achieving the objectives of the study.

\section{Acknowledgement}

Authors would like to thanks Smart Driving Research Center (SDRC), Soft Soils Research Center (RECESS) and, Faculty of Civil and Environmental Engineering that gave full support by committed technical staff to ensure all the laboratories equipments in good and functional condition.

\section{References}

Jabatan Keselamatan Jalan Raya. (2014). Pelan Keselamatan Jalan Raya Malaysia 2014-2020. Malaysia: Kementerian Pengangkutan Malaysia

Udayakumar, G. and Chandralekha S., "Devising a new technique to reduce highway barrier accidents", International Journal of Research in Engineering and Technology, 3773-780, 2009

Bhat G. A.,. Cement Factories, Air Pollution and Consequences .Universiti of Kashmir, 2013

Sareen A. K., Fasanella E., Sparks C., Jackson K., and Mullins B. R, “Comparions of hardsurface and soft soil impact performance of a crashworthy composite fuselage concept", American Helicopter Society International. 42 116-125, 2005

Hunter K. and Kiffmeyer D., "Earth bag Building: The Tools, Tricks and Techniques” New Society Publisher. 0-86571507-6, 2014

Jabatan Kerja Raya “Arahan Teknik Jalan 1/86”, Kuala Lumpur Bahagian Senggara Fasiliti Jalan, Jabatan Kerja Raya, 1986

Jabatan Kerja Raya, "Piawaian Jkr Bagi Jangka Hayat Aset Infrastruktur Dan Aset Kejuruteraan", Kuala Lumpur Bahagian Senggara Fasiliti Jalan, Jabatan Kerja Raya, 2013

Hampton C.E. and Gabler H.C, "Development of a missing post guideline for longitudinal barrier crash", Safety Journal of Transportation Engineering, 139 549-555, 2013

Gary. R., Jae H. C., and Kurtis R. G, "Impact Simulation and Full Scale Crash testing of a Low profile Concrete Work Zone Barrier" Computers and Structure 81 1359-1374, 2002 